\title{
PRAKTICKÁ INSTRUKCE PRO DLOUHODOBOU STABILIZACI POZORNOSTI - ZÁKLAD PRÁCE SE STRESEM
}

\author{
11: 1-270, 2009 \\ ISSN 1212-4117 \\ Petr Zach ${ }^{1}$, Jana Mrzílková2 ${ }^{\text {, Stanislava Kučová }}{ }^{3}$ \\ ${ }^{1}$ Jihočeská univerzita v Českých Budějovicích, Zdravotně sociální fakulta, katedra preklinických oborů \\ ${ }^{2}$ Karlova univerzita v Praze, Anatomický ústav, 3. lékařská fakulta \\ ${ }^{3}$ Karlova univerzita v Praze, Filozofická fakulta
}

\section{ÚVOD}

Zvládání stresu nefarmakologickou cestou je v centru pozornosti každé současné společnosti. Spousta lidí hledá východiska, jak se zbavit zejména endogenního stresu z náročného povolání, tíživé životní situace apod. Mezi finančně nenáročné patří velice účinná práce, která technikou dlouhodobé stabilizace vede $\mathrm{k}$ lepší distribuci pozornosti mezi vlastní pamět'ovou stopu a senzorické objekty zevního prostředí. Technika je vhodná spíše pro introspektivní typ lidí, nemajících potíže s klidným sezením na jednom místě.

\section{MATERIÁL A METODY}

Technika progresivní stabilizacepozornosti u člověka, vycházející z buddhistických textů, se v sanskrtu označuje shamata (shama znamená klid a ta spočívat). Technika obsahuje dvě hlavní instrukce, týkající se tělesné pozice a práce s myslí.

\begin{abstract}
a) pozice těla
Techniku provádíme optimálně na meditačním polštáři různé velikosti podle výšky a konstituce jednotlivce. Variantou pro pacienty s různými onemocněními zejména pohybového aparátu je sed na židli nebo vleže na lưžku. Pozice těla má pro celou techniku zásadní význam. Během shamaty zaujímáme pozici těla, která dovoluje opravdový odpočinek v kontrastu s tím, co se běžně považuje za „uvolnění se“. Běžně se za relaxovanou pozici těla považuje leh nebo sed s opěradlem. V takovýchto pozicích jsou krční, hrudní a bederní páteř a odpovídající skupiny krčního, hrudního, bederního a břišního svalstva nevyužity, často se zároveň opíráme o horní nebo dolní končetiny. Toto „vysazování z aktivity“ axiálního skeletu a jeho svalstva je
\end{abstract}

nápadné při řadě běžných lidských aktivit: řízení dopravních prostredků, sezení u počítače nebo televize či sezení obecně. Jako výhodná se zdá z tohoto hlediska v některých zemích Asie výuka dětí ve školách $\mathrm{v}$ pozici se zkřriženýma nohama na podložce.

$\mathrm{Na}$ meditačním polštáři tedy sedíme se zkř́iženýma nohama, které se nepřekřrižují, jedna končetina je více vpředu a druhá více vzadu. Během sezení je možné končetiny stř́dat. Je vhodné sedět $\mathrm{v}$ přední třetině polštáře tak, aby kolena mírila směrem dolů, a ne opačně - př̀ delších sezeních to vede $\mathrm{k}$ bolestivosti $\mathrm{v}$ kyčlích. Trup je na meditačním polštáři vytažen z kyčelních kloubů vzhưru (vzpřímené sezenî) tak, aby bylo respektováno prirozené zakřivení bederní páteře (prohnutí konvexitou směrem dopředu - lordóza). Hrudník je mírně otevřený směrem dopředu (lehce vypjatá prsa). Lopatky jsou mírně sevřeny dovnitř, směrem $\mathrm{k}$ páteřri, a ramena jsou volně spuštěna dolů. Ruce umíst'ujeme dlaněmi asi $1 / 3$ délky za koleny na stehna volně. Nepřidržujeme se rukama stehen, abychom tak udržovali rovnováhu a mohli uvolnit páteř. Celá pozice je naopak páteří podpírána. Vrcholky loktů se pak nacházejí v úrovni zadní části trupu. Krční páteř je v rovině se zbytkem páteře. Nepředsunujeme ani nezasunujeme krk vzhledem k ostatní části trupu. Hlava je bradou mírně prritažena $\mathrm{k}$ hrudní kosti tak, aby se zátylek nacházel v jedné rovině s krční páteří. Místo na vrcholku temene, kde je často vytvořen vír vlasů, by měl směřovat kolmo vzhůru. Můžeme si to zkontrolovat po zaujetí pozice pohmatem. Většinou máme pocit, že hlava je umístěna rovně na krku, když pohled směřuje rovně před nás - ve skutečnosti je pak ale mírně v záklonu. Pokud tedy máme hlavu rovně př́i sedu na meditačním polštáři, pohled automaticky směřuje $1-2 \mathrm{~m}$ před nás na podla- 
hu. Oči zůstávají pootevřené. Zásadně je nezavíráme, protože lehce dochází $\mathrm{k}$ nástupu spánku. Ústa jsou mírně otevřená a jazyk umíst’ujeme za horní zuby kvưli zamezení slinění.

Pozice je pro nás na počátku nezvyklá, může být i nepř́ijemná. Neměla by však být bolestivá. Pokud máme během techniky bolesti, snažíme se pracovat $\mathrm{s}$ výškou polštáře, s pozicí páteře, s uspořádáním dolních končetin tak, abychom našli pozici, která je pro nás přijatelná. To může nějakou dobu trvat. Pokud se nám podaří vhodnou pozici najít a zvykneme si na ni, čas strávený v ní budeme za nějakou dobu vnímat jako odpočinek. $Z$ anatomického hlediska je výše popsaná pozice těla během techniky doplňkem a kontrastem k pozici, v níž trávíváme většinu dne. Jako celek by pro nás měla pozice vyznít poněkud důstojným dojmem, v literatuře se užívá termín „král(ovna) na svém trůnu“. U dlouhodobě hospitalizovaných pacientů je často nutné pracovat s pozicí vleže, podobně jako u handicapovaných lidí je nutno pozici prrizpůsobit jejich možnostem (různé podkládání končetin, zvláštní stoličky apod.).

\section{b) práce s pozorností (myslí)}

Jakmile zaujmeme přiměřeně správnou pozici těla, zjistíme, že ,jen tak sedět a nedělat nic“ je velice problematické. Automaticky se předpokládá, že nedělat nic by neměl být problém, ale je. Jedním z problémů je to, že nejsme na podobnou situaci zvyklí. Za každých okolností máme tendenci mít nějaký plán, něco dělat. Pokud se rozhodneme, že odpočíváme, stejně probíhá nějaká činnost (četba knihy, rybaření, spánek apod.). Zde ale jsme však v nové situaci, pokud jsme se již s technikou dřive nesetkali. Pravděpodobně jsme totiž nikdy v životě nebyli $\mathrm{v}$ situaci, kdy bychom měli prostor pro to, abychom opravdu nic nedělali. Co se s námi $\mathrm{v}$ takové situaci tedy děje? Velice časté je zjištění, že máme celý vodopád myšlenek, pocitů, vzpomínek, fantazií, které se zběsilou rychlostí objevují a zase mizí. Nebo máme pocit prázdnoty a obavy, co bude. Pro někoho může být překvapením, kolik se toho $\mathrm{v}$ našem vědomí odehrává, ačkoliv spočíváme fyzicky na jednom místě. Pro spoustu lidí bude jenom tato fáze celé techniky nepřijatelná a nepodaří se jim techniku opakovaně provádět. Př́i prvém sednutí si na meditační polštář je častá mrzutost, zlost nebo podráždění. Pro někoho jiného bude uvedení do techniky jako rozpomenutí se na něco dávno známého a velice prrijatelného.

Jakmile tedy zaujmeme pozici těla, máme zjednodušeně vzato dvě možnosti: a) necháme všechno běžet, tak jak to je, odměríme si př́slušnou dobu na časomíře a po uplynutí času zase vstaneme; nebo b) používáme referenční bod, za který se tradičně doporučuje dech (nádech či výdech nebo obojî). Referenční bod se doporučuje, protože pozornost má spontánní tendenci vyhledávat, ulpívat a nechat se pohlcovat myšlenkami, emocemi, vzpomínkami, objekty senzorických orgánů apod. Pokud tedy necháme během sezení pozornost bez referenčního bodu, často se tento proces ulpívání zrychluje až do bodu, kdy máme pocit nezvladatelnosti a bezmoci. Pak je dobré aplikovat referenční bod. Zpočátku jím může být také počítání nádechů a výdechů jako jednoho cyklu až do deseti a pak znovu od jedničky.

Když poprvé provádíme techniku, míra našeho vyrušení bývá značná. Jakmile si uvědomíme, že se naše pozornost vzdálila od dechu, bez násilí a jemně ji zase umístíme na dech. To je jádro instrukce práce s pozorností. Abychom si zpočátku lépe poradili s tím vším, co se nám během provádění techniky ve vědomí odehrává (myšlenky, pocity, fantazie, bolest apod.), můžeme si to všechno zjednodušeně označovat jako myšlení. Technicky vzato, jakmile se objeví myšlenka, představa, pocit nebo bolest, vezmeme razítko, „orazítkujeme“ to a necháme běžet. K zlepšení stability pozornosti vede zejména počet návratů na dech během meditačního sezení. Pro specializovanější prehled a vysvětlení techniky shamata (viz Sakyong, 2002; Trungpa, 1995).

\section{c) poznámky $\mathrm{k}$ práci s pozorností}

Zpočátku pro nás bývá nesnadné, ne-li nemožné, udržet pozornost na dechu po více než 4 dechové cykly. Pokud se nám to i daří, nejsme schopni to při pryíśtím sezení zopakovat. Stabilita mysli ještě není výrazná. Nepropadejme zklamání, techniku je nutno provádět alespoň 3 měsíce každý den 5 minut, aby se dostavilo elementární zlepšení stability pozornosti.

Během sezení se neuzavíráme do sebe, tak abychom neslyšeli, neviděli nebo nevnímali právě naopak. Vše, co $\mathrm{k}$ nám dolehne, zvuk, 
vůně apod., si uvědomíme, ale po krátké době zase pozornost vracíme zpět na dech. $\mathrm{V}$ žádném případě neunikáme do snového světa, to by byl chybný př́stup. Zpočátku je celá technika pro nás téměř náročnou prací, teprve s postupem času si na ni zvykneme a provádíme ji uvolněněji. Tuto fázi nelze přeskočit, ani jinak nahradit.

To, co se nám vyjevuje během meditace z paměti (vzpomínky na školní ubrus na základní škole, pes sousedů, koho je dnes ještě potřeba navštívit apod.), při prvém pohledu nemá žádnou logiku a děje se to nahodile. Máme pocit, že nejsme v situaci, kdy bychom mohli ovlivnit tok představ $z$ paměti (krátkodobé i dlouhodobé). Naše představy (termín představa autor chápe jako předsunutí obsahu mysli před vědomou pozornost) mohou mít bizarní obsah a chaotickou strukturu. To je zajímavá část našich sezení, ve kterých se často poprvé ve svém životě, bez ohledu na věk, seznamujeme s dynamikou a strukturou svých mentálnèemočních obsahů (odtud tibetský termín pro meditaci gom - obeznamování se s něčím, meditační polštář den, gomden - polštář pro obeznamování se s něčím). Ačkoliv máme pocit, že máme v životě řadu zkušeností, tento zážitek můžeme prodělat pouze $\mathrm{v}$ jistém uspořádání situace. Rychlost, shon, účel a řada jiných faktorů znemožňují zažít tuto základní lidskou vlastnost v běžném nastavení situace.

\section{d) předpoklady pro provádění techniky} shamata

Obecné předpoklady:

- cvičení provádíme uvnitř místnosti, ne na volném prostranství;

- pro cvičení si vyhradíme místo, kde po dobu alespoň 5-10 minut můžeme setrvat nerušeni;

- alespoň ze začátku cvičení provádíme ráno. Večer je organismus vyčerpán a techniku je obtížnější provádět;

- obecné zásady dobré životosprávy (dostatek spánku, přiměřená strava - tyto faktory mohou pozitivně, nebo negativně ovlivňovat průběh a výsledek provádění techniky);

- meditační polštářek přiměřené velikosti $\mathrm{k}$ praktikujícímu pro pozici vsedě na podlaze.

Intrinsické (intrapsychické) předpoklady:
- schopnost elementární sebereflexe (vývojově dolní hranice u dětí 4.-6. roku věku, psychologicky u střední populace vědomí existence emocí, myšlenek, návykových vzorců bez pojmenování, vůle a ochota $\mathrm{k}$ provádění mentálních operací směřujících k hlubšímu sebepoznání;

- při samostatném praktikování techniky bez vedení se předpokládá psychomotorická integrita, nepŕítomnost psychiatrických postižení (klinická deprese, schizofrenie, neurotické a neurastenické potíže a dalšî) a trpělivost.

\section{e) časté otázky a problémy}

Hluk v okolí (kroky na chodbě, štěkající pes $\mathrm{v}$ dálce, zvuk telefonu apod.) nepředstavuje pro techniku problém. Nesnažíme se hluk odstínit nebo si jej nevšímat - naopak, uvědomíme si jej, můžeme si všimnout jeho kvality a vracíme pozornost zpět na dech. Pokud máme pocit, že hluk zcela pohltil naše vnímání, vstaneme, jdeme se projít a za nějakou dobu se opět $\mathrm{k}$ technice vrátíme.

\section{VÝSLEDKY}

Výsledky mohou být rozděleny na krátkodobé a dlouhodobé. Mezi krátkodobé patři dopad na spánek. U řady pacientů vede 15-20minutové sezení před spánkem nebo $\mathrm{v}$ průběhu noci po probuzení a nemožnosti usnout $\mathrm{k}$ podobnému efektu jako použití farmakologického hypnotika. Efektu je docíleno relativním snížením velkých a dlouhých řetězců představ a tím snížením aktivity vědomí na fyziologické úrovni oboustrannými thalamo-kortikálními spoji.

Dlouhodobý efekt se dostavuje až zhruba po několika měsících denního praktikování techniky a je často z hlediska praktikujícího pro pozvolný nástup těžko postižitelný. Dochází ke stabilizaci složek vědomé pozornosti. Podobně jako růst vlasů nebo nehtů není prímo zachytitelný, pozvolný nárůst stability pozornosti přichází pomalu. Subjektivně se zlepšuje nálada, na rozhraní komunikace s okolím pak dochází ke stažení pozornosti na události a jevy probíhající momentálně, viz príklad s řízením automobilu (Zach, Mrzílková, 2008). Během jakékoliv denní činnosti pak má pozornost tendenci rychleji se vracet $\mathrm{k}$ přítomnému okamžiku, což má zásadní vliv na tělesné i duševní zdraví. Neznamená to, že by nebyla možnost setrvávat ve vzpomín- 
kách, naopak, pokud se tak bude dít, pak se zvýšenou stabilitou. Výcvik pozornosti tedy vede k posílení její schopnosti setrvávat $\mathrm{v}$ př́ípadě přání na zvoleném objektu. I mimo vědomé zaměřování pozornosti se výcvik projeví celkovým snížením rychlosti spontánních přeskoků z objektu na objekt, což vede k celkové úlevě od únavy. Dalším aspektem výcviku je vyšší integrace složek vědomí jednotlivce. Běžně jsou ve vědomí přítomny části senzorických nebo viscerálních vjemů a pamět'ových událostí bez možnosti ovlivnění jejich zastoupení. To vede $\mathrm{k}$ vyšší únavnosti organismu. Část paměti a emocí není naopak pozorností zohledněna a vědomě či nevědomě se tak vytvářejí latentní ložiska, která se často dostanou na povrch v nejnevhodnější chvíli a mají značný vliv na další život. Bez výcviku pozornosti si nemáme možnost uvědomit, že popsaný proces probíhá po celý náš život, a my marně hledáme lék nebo pomoc, která by zabrala.

Pro přehled neurofyziologických a klinických poznatků práce s pozorností meditativní technikou (viz Cahn a Polich, 2006; Shapiro et al., 2008; Zach, Mrzílková, 2008).

\section{ZÁVĚR}

Uvedená technika práce s pozorností je metodologickým nástrojem pro stabilizaci pozornosti. Její efekt nastupuje zpravidla s dlouhodobým prováděním (3 měsíce každodenního prováděnî). Dosažení vyšší stability pozornosti touto cestou je spojeno s možností lépe pracovat s přicházejícími senzorickými informacemi $\mathrm{v}$ prrítomný moment, tak s lepší orientací v individuální pamět'ové stopě. $S$ délkou provádění techniky může být spojeno zlepšení funkce různých funkčních systémů jako např. vysokého tlaku, neuropsychiatrických potíží, dermatitid, pohybového aparátu a dalších. Mezi předpoklady provádění techniky patří náhlá dramatická událost $\mathrm{v}$ životě, vrozené schopnosti spočívat pozorností jednobodově na zvoleném objektu, kontextuální faktory (př́tomnost skupiny lidí, kteř́ již techniku provádějî) a celkové introspektivní ladění osobnosti. Techniku je možné provádět $\mathrm{v}$ pozici vsedě nebo vleže u dlouhodobě hospitalizovaných pacientů a také $\mathrm{v}$ chůzi.

\section{LITERATURA}

CAHN, B. R., POLICH, J.: Meditation states and traits: EEG, ERP, and neuroimaging studies. In: Psychology Bulletin, 2006. Vol. 132, no. 2, p. 180-211.

SAKYONG, J. M. R.: Seminary transcripts. Teachings from the Sutra Tradition - Book One. 1. ed., Halifax: Vajradhatu Publications, 2002. p. 29-57.

SHAPIRO, S. L. et al.: Cultivating mindfulness: effects on well-being In: Journal of Clinical Psychology, 2008. Vol. 64, no. 7, p. 840-862.

TRUNGPA, CH.: Protnutí duchovního materialismu. 1. vyd., Jablonec nad Nisou: Vadžra, 1995.

ZACH, P., MRZÍLKOVÁ, J.: Technika nácviku vědomé pozornosti ve zdraví i nemoci. In: Kontakt, České Budějovice: JU ZSF 2008. no. 1, p. 209-213. 